Brazilian Review of Finance - Revista Brasileira de Finanças (RBFin)

Editorial Report - 2010

Ricardo P. Câmara Leal, Editor

\begin{abstract}
RBFin is the main publication outlet for academic papers on finance in Brazil. The contents of the Review are open and online; a printed version is maintained, in part, thanks to a grant from CNPq/CAPES. Using the Open Journals System to manage the editorial process, publication of RBFin adheres to a strict publication schedule. The journal is indexed by EconLit, Google Scholar, DOAJ, Gale and Ebsco and is listed in the JEL, Latindex, and Cabell's directories. RBFin is rated B1 in the business area of the Brazilian classification system. The editorial board undergoes partial turnover every year and comprises 18 individuals from five countries, the Brazilian members being affiliated with universities in five different Brazilian states. The acceptance rate was $22.9 \%$ for papers submitted in 2009 and $19.7 \%$ for 2010 . The average number of days between receipt and acceptance for all articles published in 2010 was 215 . The worst case was 525 days. The average number of days between receipt and publication was 367. The worst case was 649 days. The average number of hits per article as of January 2011 was 1027 . In 2010, 117 individuals served as reviewers.
\end{abstract}

\title{
Introduction
}

This report presents the main aspects of the development of RBFin in 2010, together with summary editorial and distribution statistics. The number of articles submitted this year was the largest in the history of the Review. RBFin maintained a Web interface for submission and evaluation of articles and free access to its content, continued the ongoing process of Editorial Board turnover and listed its contents in the Directory of Open Access Journals (DOAJ). Although the review commenced use of English as the main language on the website as well as in the print version, articles in both Portuguese and English are accepted. This is an intermediate step towards full conversion to English in the future. It is expected that all developments will lead to significant improvements in the editorial process and in the overall quality of RBFin. The Review continues to be partially supported by a $\mathrm{CNPq} / \mathrm{Capes}$ grant.

\section{Advances in 2010}

The publication schedule of RBFin is strictly up to date. There was continuity in the process of renewal of the Editorial Board, as detailed below. The contents of the Journal remained online and open and the printed version, which is distributed to members of the Brazilian Finance Society and to selected libraries, has been maintained, thanks to the financial assistance from the CNPq/CAPES grant. The 


\section{Brazilian Review of Finance - Revista Brasileira de Finanças (RBFin)}

process of submission and assessment of articles is done entirely online through the Open Journals System (OJS). OJS allows all correspondence and versions of the papers to be stored in the system. All content is stored on the servers of Fundação Getulio Vargas (FGV) in Rio de Janeiro and is protected by the security and data preservation procedures of that institution. OJS allows submission of a variety of metadata, such as title, abstract, keywords and JEL indexing codes, which can be integrated with systems for the dissemination of academic journals that employ the Open Archives Initiative technology. This mechanism provides authors with a wider dissemination of their articles. In addition, there is the permanent maintenance and improvement of the website and of the editorial process.

With its open content, it was possible to integrate the Review with Google Scholar. The Review has already been indexed in EconLit and Google Scholar and is listed in the JEL, Latindex and Cabell's directories. In 2009, the Review was included in the Gale and Ebsco databases, and in 2010 it entered the Directory of Open Access Journals (DOAJ). We also applied for inclusion in the Scopos database. In the near future we will consider the benefits of including RBFin in RePEc, Scielo and Redalyc (Scientific Journals Network of Latin America and the Caribbean, Spain and Portugal).

According to the Capes (Ministry of Education) scale, RBFin was rated B1 in the Business Administration and Accounting area and B3 in Economics. We hope that future entry of RBFin in other indexing databases will further improve ratings.

\section{SBFin Best Paper Award}

During the Brazilian Finance Meeting of July 2010, the SBFin (Brazilian Finance Society) Best Paper Award for an article published in 2009 (volume 7) was awarded R \$10,000. The award went to Market overreaction to intangible information, by Carlos Marcelo Lauretti (Mackenzie Presbyterian University), Eduardo Kazuo Kayo (FEA/USP) and Emerson Fernandes Marçal (Mackenzie Presbyterian University). Honorable mentions were awarded to two articles: Is it possible to replicate the exchange rate volatility behavior using dynamic strategies?, by Ronny Woo Kim, José Valentim Vicente Machado and Claudio Henrique Barbedo, all affiliated with Ibmec, RJ, and Market reaction to the approval of stock options plans: an event study of Bovespa listed companies, by Aline Barreto dos Santos and Fernanda Finotti Perobelli, both affiliated with Federal University of Juiz de Fora. The SBFin Award is bestowed on the best paper in the opinion of a committee formed by the chief editor and the four associate editors. 


\section{Editorial Board}

All members of the Editorial Board serve for a renewable three-year term and commit to evaluate up to two articles per year, in addition to helping assign reviewers to submitted papers. Of the 18 members of the Editorial Board at yearend 2010, eight had finished their terms and seven had terms expiring by the end of 2011. The permanent renewal of the regionally and internationally diversified 18-member Editorial Board aims to maximize engagement with the editorial process. For 2011, there will be no change in the number of members or international and national diversification.

Beginning in 2010, the following became members of the Editorial Board: Alexandre di Miceli da Silveira (University of São Paulo), Ana Paula Serra (University of Porto), Heitor de Almeida (renewed appointment, University of Illinois), Marcelo Fernandes (Queen Mary University), Márcio Nakane (University of São Paulo), Pedro Saffi (IESE, University of Navarra), and Rodrigo de Losso da Silveira Bueno (University of São Paulo). For the 2010 to 2012 terms, the following appointments were renewed: Daniel Ferreira (London School of Economics and Political Science) and Murillo Campello (University of Illinois). Rodrigo Verdi (MIT) joined the Editorial Board, replacing Armando Gomes (Washington University in Saint Louis).

From 2011, the following individuals joined the Editorial Board: André C. da Silva (New University of Lisbon, Portugal), Gustavo Manso (MIT, USA) and Paulo R. S. Terra (Federal University of Rio Grande do Sul) with appointments from 2011 through 2013. For the same time period, the following appointments were renewed: Antonio Zoratto Sanvicente (Insper Institute of Education and Research, São Paulo), Benjamin Tabak (Catholic University of Brasília), Caio Almeida (Graduate School of Economics, Getulio Vargas Foundation, Rio de Janeiro), Fernanda Perobelli (Federal University of Juiz de Fora, Minas Gerais) and Márcio Garcia (Pontifical Catholic University of Rio de Janeiro). 
Brazilian Review of Finance - Revista Brasileira de Finanças (RBFin)

Table 1: Editorial Board Statistics

\begin{tabular}{lcc}
\hline Country/State & End of 2010 & From 2011 \\
\hline Brazil & 10 & 9 \\
$S P$ & 4 & 4 \\
$R J$ & 2 & 2 \\
$D F$ & 1 & 1 \\
$E S$ & 1 & 0 \\
$M G$ & 1 & 1 \\
$R S$ & 1 & 1 \\
USA & 3 & 4 \\
Portugal & 2 & 2 \\
UK & 2 & 2 \\
Spain & 1 & 1 \\
\hline Total & 18 & 18 \\
\hline
\end{tabular}

\section{Editorial Policy Committee}

The committee comprises the president of SBFin, Richard Saito, SBFin publication directors Márcio Garcia and Paulo Terra, and the chief editor of the Review, Ricardo Leal. The committee is charged with the main policy issues of the Review, such as format, frequency of publication, Editorial Board appointments, special issues, and any other policies and major decisions regarding the Review. The key decisions of this committee are submitted to the board of directors of SBFin.

\section{Editorial Statistics}

Table 2 shows key statistics of the RBFin editorial process, as of December 31, 2010. The acceptance rate in relation to the total number of articles with a final decision (accepted, rejected, withdrawn) was $19.7 \%$ for 2010 . The acceptance rate will presumably increase when all articles still under review have received a final decision. The editors reject about $25 \%$ of the articles without sending them to reviewers. The acceptance rate for articles submitted in 2009 (year in which all articles have already received a final decision) was $22.9 \%$. For the articles published in 2010, volume 8 , issues $1,2,3$, and 4, the average number of days between receipt and acceptance was 215 , with the worst case being 525 days. The average number of days between receipt and publishing was 367, with the worst case being 649 days. Average times for 2010 are similar to those of 2009. Twenty articles were published in 2010 . 


\section{Distribution and Access}

Since the opening of the Review contents, in July of 2008, the total number of Internet accesses was 107,906 for its 105 articles, with an average of 1,027 accesses per article. Of the total of number of hits, $20 \%$ were for the English version of the website. These numbers were obtained on January 10, 2011.

Hard copy issues of RBFin are distributed to the individual members of the Brazilian Finance Society and are sent at no cost to several libraries in Brazil and abroad. The Review is distributed to all participants of the Brazilian Finance Meeting, and each author received three copies of the issue in which their article has been published. Table 3 shows the distribution statistics of the Review.

Table 2: Editorial Statistics of the Articles Submitted by the end of December, 2010

\begin{tabular}{lc}
\hline Articles received & 84 \\
Articles accepted & 12 \\
Articles rejected & 48 \\
Articles withdrawn by authors & 1 \\
Articles under review & 12 \\
Articles under revision by authors & 11 \\
Published articles & 20 \\
Articles under review from previous years & 0 \\
Articles under revision by authors from previous years & 0 \\
Articles accepted but not yet published & 8 \\
Inventory (under review, revision, and accepted but not published) & 31 \\
\hline
\end{tabular}

Table 3: Hard Copy Distribution Statistics (Volume 8, Issue 4, 2010)

\begin{tabular}{lc}
\hline SBFin Members & 157 \\
Donations to Brazilian libraries & 63 \\
Donations to foreign libraries & 7 \\
Permutations & 0 \\
\hline Total & 227 \\
\hline
\end{tabular}




\title{
List of Reviewers (by first name)
}

Producing a good quality academic publication depends on the engagement of highly qualified academics in the article evaluation process. The editors of RBFin would like to thank the 117 individuals below, who performed voluntary evaluation of the articles that completed their review process in 2010. Eighteen of these reviewers work in foreign universities. According to RBFin policy, each reviewer may perform no more than one review per year, with the exception of follow-up reviews of the same article. We show the number of papers reviewed when this limit was exceeded.

\author{
A. Gledson de Carvalho, EAESP/FGV, Brazil \\ Abu Jalal, Suffolk University, UK \\ Adrian Pizzinga, DEE/PUC-Rio, Brazil \\ Ajax Moreira, IPEA, RJ, Brazil \\ Alan Dario, B\&MFBovespa, SP, Brazil \\ Alberto Matsumoto, DA/Universidade Católica de Brasília, Brazil \\ Alexandre di Micelli, FEA/USP, Brazil \\ André Luiz Carvalhal da Silva, PUC-Rio, Brazil \\ Andrea Minardi, Insper, SP, Brazil \\ Antonio Carlos Figueiredo (2), PUC-Rio, Brazil \\ Antonio Zorato Sanvicente, Insper, SP, Brazil \\ Arilton Teixeira, Fucape, ES, Brazil \\ Aureliano Bressan (2), FACE/UFMG, Brazil \\ Axel Simonsen, EPGE/FGV, RJ, Brazil \\ Beatriz Mendes (2), IM/UFRJ, Brazil \\ Benjamin Tabak (2), UCB/Banco Central do Brasil, DF, Brazil \\ Bruno Lund, EPGE/FGV, RJ, Brazil \\ César Cupertino, DEP/UFSC, Brazil \\ Charles Carmona, DCA/UFPE, Brazil \\ Claudio Alencar, POLI/USP, Brazil \\ Cláudio Cunha, UFES, Brazil \\ Clemens Vinícius Nunes, EESP/FGV, SP, Brazil \\ Cristiano Fernandes, DEE/PUC-Rio, Brazil \\ Daniel Cajueiro, DE/UNB, Brazil \\ Daniela Kubudi, EPGE/FGV, RJ, Brazil \\ Edson Daniel Lopes Gonçalves, EPGE/FGV, RJ, Brazil \\ Eduardo Kayo, FEA/USP, Brazil \\ Elmo Tambosi Filho, Universidade Metodista de São Paulo, Brazil \\ Erik Figueirêdo, UFPB, Brazil \\ Eurílton Alves Araújo Jr, Insper, SP, Brazil \\ Fábia de Carvalho, Banco Central do Brasil, Brazil \\ Fábio Gallo Garcia, EAESP/FGV, Brazil \\ Fernanda Perobelli (2), DE/UFJF, MG, Brazil
}


Fernando Aiube, PUC-Rio, Brazil

Fernando Murcia, UFSC, Brazil

Flávio Ziegelmann, IM/UFRGS, Brazil

Giovani L. Vasconcelos, LFTC/UFPE, Brazil

Graziela Fortunato, Fucape, ES, Brazil

Gustavo Amorim Antunes, Secretaria do Tesouro Nacional, DF, Brazil

Helder Parra Palaro, City University, UK

Herbert Kimura, Universidade Presbiteriana Mackenzie, SP, Brazil

Hsia Hua Sheng, EAESP/FGV, Brazil

Hudson Amaral, FACE/UFMG, Brazil

Jairo Procianoy, EA/UFRGS, Brazil

James Angel, Georgetown University, USA

Jaqueline Marins, Banco Central do Brasil, RJ, Brazil

João Carlos Douat, EAESP/FGV, Brazil

João Froes Caldeira, PPGE/UFRGS, Brazil

João Leitão, Universidade Técnica de Lisboa, Portugal

João Luiz Chela, Universidade Presbiteriana Mackenzie and BM\&F, SP, Brazil

João Victor Issler, EPGE/FGV, RJ, Brazil

Joe Yoshino, FEA/USP, Brazil

Joel Correa da Rosa, Estatística, UFF, RJ, Brazil

José Fajardo Barbachan (2), Ibmec/RJ, Brazil

José Luiz Fernandes, Banco Central do Brasil, Brazil

José Renato Haas Ornelas, Banco Central do Brasil, Brazil

José Valentim Vicente, Banco Central do Brasil, RJ, Brazil

Julia von Maltzan Pacheco, EESP/FGV, Brazil

Kalu Ojah, University of the Witwatersrand, South Africa

Kátia Rocha, IPEA, RJ, Brazil

Kevin Aretz, Lancaster University, UK

Liang Song, Renssalaer Polytechnic Institute, USA

Lucas Barros, Universidade Presbiteriana Mackenzie, SP, Brazil

Luis Paulo Lopes Fávero, FEA/USP, Brazil

Luiz Antonio da Rocha Dib, Coppead/UFRJ, Brazil

Luiz Felipe Jacques da Motta, IAG/PUC-Rio, Brazil

Luiz Koodi Hotta, IME/Unicamp, Brazil

Manoel Armada, Universidade do Minho, Portugal

Marcelo Fernandes, Queen's University, UK

Marcelo Klotzle, IAG/PUC-Rio, Brazil

Marcelo Medeiros, Econ/PUC-Rio, Brazil

Marcelo Mello, Ibmec/RJ, Brazil

Marcelo Moura, Insper, SP, Brazil

Márcio André Veras Machado, PPGA/UFPB, Brazil

Márcio Poletti Laurini, Ibmec/RJ, Brazil

Marcos Rietti Souto, Fundo Monetário Internacional, USA

Milton Barossi Filho, FEARP/USP, Brazil 
Moisés Resende, Economia/UNB, Brazil

Murillo Campello, University of Ilinois, USA

Myrian Neves, Banco Central do Brazil, RJ, Brazil

Nelson Tanaka, IME/USP, Brazil

Newton Costa Jr (2), Econ/UFSC, Brazil

Patrícia Bortolon, UFES, Brazil

Patrick Behr, Goethe University Frankfurt, Germany

Paulo Ceretta, UFSM, RS, Brazil

Paulo Terra, EA/UFRGS, Brazil

Pedro Boainain, Itaú Unibanco, Brazil

Pedro Paulo Schirmer, IME/USP, Brazil

Pedro Saffi, IESE, Spain

Pedro Valls Pereira, EESP/FGV, Brazil

Rafael Martins de Souza, IBGE, Brazil

Rafael Moura, EPGE/FGV, RJ, Brazil

Rafael Rezende, Stockholm School of Economics, Sweden

Ralph S. Silva, University of New South Wales, Australia

Raúl Iñiguez, Universidad de Alicante, Spain

Reinaldo Guerreiro, FEA/USP, Brazil

Renato Vicente, EACH/USP, Brazil

Ricado P. C. Leal (6), Coppead/UFRJ, Brazil

Ricardo Brito (2), Insper, SP, Brazil

Robert Iquiapaza, UFMG, Brazil

Roberto Decourt, PPGA/UFRGS, Brazil

Roberto Meurer, Econ/UFSC, Brazil

Rodrigo Atherino, PUC-Rio, Brazil

Rodrigo de Losso (2), FEA/USP, Brazil

Rodrigo Okimura, Universidade Presbiteriana Mackenzie, SP, Brazil

Rodrigo Zeidan, University of Nottinghan, UK

Rogério Sobreira, EBAPE/FGV, RJ, Brazil

Silvinha Vasconcellos, FE/UFJF, MG, Brazil

Thelma Sáfadi, DCE/UFLA, Brazil

Tiago Wickstrom Alves, Unisinos, Brazil

Vinício Almeida, UFRN, Brazil

Walter Lee Ness, IAG/PUC-Rio, Brazil

Walter Novaes, Econ/PUC-Rio, Brazil

Wesley Mendes da Silva, Universidade Presbiteriana Mackenzie, SP, Brazil

William Eid Jr, EAESP/FGV, Brazil

Wilson Nakamura (2), Universidade Presbiteriana Mackenzie, SP, Brazil

Zhaoyang Gu, University of Minnesota, USA

Rio de Janeiro, March 4, 2011. 